\title{
Sterile versus nonsterile clean dressings
}

\author{
Moraya Alqahtani MBBS ${ }^{1}$, Donald H Lalonde MD BSc MSc FRCSC ${ }^{2}$
}

M Alqahtani, DH Lalonde. Sterile versus nonsterile clean dressings. Can J Plast Surg 2006;14(1):25-27.

BACKGROUND: Many patients cannot afford sterile dressings. In St John, New Brunswick, clean dressings have been used instead of sterile dressings for years, with no apparent ill effects. No previous studies have compared the sterility and cost of clean versus sterile dressing materials.

OBJECTIVES: The goals of the present study were to answer the following questions: how much more sterile are sterile dressings than clean dressings; and how much does this extra sterility cost?

METHODS: Sterility and cost of sterile gauze, panty liners, sanitary napkins, diapers and Coban tape (3M, USA) were compared. Samples, $2 \mathrm{~cm} \times 2 \mathrm{~cm}$ in size, were cut out of each material under aseptic conditions, and delivered to the microbiology laboratory in sterile urine containers. The samples were then cultured and organisms were identified using conventional means.

RESULTS: The cost for one month, using one $20 \mathrm{~cm} \times 5 \mathrm{~cm}$ wound dressing daily, was calculated and compared with panty liners $(\$ 2.43)$, sanitary napkins $(\$ 5.55)$, diapers $(\$ 9.39)$ and Coban tape $(\$ 0.66)$, which were much cheaper than sterile dressings (\$16.50). How sterile were the dressings? None of the 20 sanitary napkins grew bacteria, one of the 20 panty liners grew bacteria (coagulase-negative Staphylococcus), two of 20 sterile dressings grew bacteria (one coagulase-negative Staphylococcus and one nonhemolytic Streptococcus), 15 of 20 diapers grew bacteria (all bacillus) and two of five Coban rolls grew bacteria (one bacillus and one coagulase-negative Staphylococcus). CONCLUSION: The panty liners, sanitary napkins and Coban tape studied were cheaper than, and had a comparible sterility with, the sterile gauze examined.

Key Words: Clean dressing; Dressing cost; Sterile dressing; Wound

\section{Pansements stériles versus propres non stériles}

HISTORIQUE : De nombreux patients ne peuvent s'offrir de pansements stériles. À Saint-Jean, au Nouveau-Brunswick, depuis des années, des pansements propres sont utilisés à la place de pansements stériles sans complications apparentes. Aucune autre étude n'avait encore comparé la stérilité et le coût des fournitures pour pansements propres versus stériles. OBJECTIFS : Les objectifs de la présente étude étaient de répondre aux questions suivantes : à quel point les pansements stériles sont-ils plus stériles que les pansements propres et, le cas échéant, combien cette stérilité accrue coûte-t-elle?

MÉTHODES : On a comparé la stérilité et le coût de la gaze stérile et ceux des serviettes et mini-serviettes sanitaires, couches et ruban adhésif Coban. Des échantillons de $2 \mathrm{~cm}$ par $2 \mathrm{~cm}$ de chaque type de protection ont été découpés dans des conditions aseptiques et acheminés vers un laboratoire de microbiologie dans des contenants pour culture d'urine stériles. Ces échantillons ont ensuite été mis en culture et les agents pathogènes ont été identifiés par la méthode standard.

RÉSULTATS : Le coût des pansements a été calculé sur la base d'une pièce de $20 \mathrm{~cm}$ sur $5 \mathrm{~cm}$ appliqué une fois par jour pendant un mois; on l'a ensuite comparé à celui des mini-serviettes sanitaires $(2,43 \$)$, des serviettes sanitaires (5,55\$), des couches $(9,39 \$)$ et du ruban Coban $(0,66 \$)$, qui s'est révélé beaucoup moins élevé que celui des pansements stériles (16,50 \$). Quelle était la stérilité de ces pansements? Aucune des 20 serviettes sanitaires n'a fait croitre de bactéries; une des 20 mini-serviettes sanitaires a permis la croissance de bactéries (staphylocoque coagulase-négatif), deux des 20 pansements stériles ont donné lieu à la croissance de bactéries (un staphylocoque coagulase-négatif et un streptocoque non hémolytique), 15 couches sur 20 ont donné lieu à la croissance de bactéries (bacille dans tous les cas) et deux des cinq rouleaux Coban ont donné lieu à une croissance de bactéries (un bacille et un staphylocoque coagulase-négatif).

CONCLUSION : Les mini-serviettes et serviettes sanitaires et le ruban Coban étudiés se sont révélés moins coûteux que les gazes stériles étudiées et dotés d'une stérilité comparable.
I $\mathrm{t}$ is commonly believed that open wounds require sterile wound dressings to hinder the introduction of bacteria. Patients feel obliged to buy expensive sterile dressings and many cannot afford them. Hospitals spend very large sums of money on sterile dressings, and virtually never use clean dressings. Yet, we and others (1), have not been able to find studies on the effect of sterile versus clean nonsterile dressings on wounds.

In St John, New Brunswick, clean dressings have been used instead of sterile dressings for years with no apparent ill effects. Therefore, it was decided to study the sterility and cost of sterile gauze versus that of panty liners, sanitary napkins, diapers and Coban tape (3M, USA). We looked at two issues: how much more sterile are sterile dressings than clean dressings, and how much does this extra sterility cost?

\section{MATERIALS AND METHODS}

Samples, $2 \mathrm{~cm} \times 2 \mathrm{~cm}$ in size, were cut out of all the materials (Table 1) under aseptic conditions and delivered to the microbiology laboratory in sterile urine containers. Thioglycolate broth was added to each sample. Each sample was incubated at $37^{\circ} \mathrm{C}$ for $48 \mathrm{~h}$ in ambient air. Samples where the broth appeared slightly cloudy were transferred using sterile technique to the surface of a sheep blood agar plate. These plates were incubated at $37^{\circ} \mathrm{C}$ for $24 \mathrm{~h}$. If growth occurred, the organisms were identified using conventional means. The prices of different products were also compared at local shopping stores.

\section{RESULTS}

Panty liners, sanitary napkins, diapers and Coban tape were found to be much cheaper than sterile dressings (Table 2).

\footnotetext{
${ }^{1}$ Plastic Surgery, Dalhousie University, Halifax, Nova Scotia; ${ }^{2}$ St John Regional Hospital, St John, New Brunswick

Correspondence and reprints: Dr Moraya Alqahtani, 67 Keyworth Lane, Halifax, Nova Scotia B3P 2T6. Telephone 902-446-5388,

fax902-446-5388, e-mail malqahtani@dal.ca
} 
TABLE 1

The specimens and materials used in the present study

\begin{tabular}{lc}
\hline Specimen & Quantity \\
\hline 5 specimens of sterile gauze $\times 4$ sizes & 20 \\
5 specimens $\times 4$ brands of panty liners & 20 \\
5 specimens $\times 4$ brands of sanitary napkins & 20 \\
5 specimens $\times 4$ brands of diapers & 20 \\
5 specimens of Coban tape $(3 \mathrm{M}$, USA $)$ & 5 \\
\hline
\end{tabular}

A total of 85 specimens had sterility examined

TABLE 2

Cost of one unit, of each material, in Canadian cents

\begin{tabular}{llc}
\hline & Sample & Cost per unit \\
\hline Sterile gauze & $2 \mathrm{~cm} \times 2 \mathrm{~cm}$ & 35 \\
& $4 \mathrm{~cm} \times 4 \mathrm{~cm}$ & 40 \\
& $4 \mathrm{~cm} \times 8 \mathrm{~cm}$ & 45 \\
Panty liners & Abdominal pads & 55 \\
& Always (Procter \& Gamble, USA) & 11.08 \\
& Care free (McNeill PPC, USA) & 7.15 \\
& Compliments (Patents, USA) & 4.2 \\
Sanitary napkins & 10.02 \\
& Kotex (Kimberly-Clark, USA) & 23.58 \\
& Always (Procter \& Gamble, USA) & 17.87 \\
& Stay free (McNeill PPC, USA) & 11.08 \\
Diapers & Compliments (Patents, USA) & 21.45 \\
& Kotex (Kimberly-Clark, USA) & 31.22 \\
& Pampers (Procter \& Gamble, USA) & 47.80 \\
& Huggies (Kimberly-Clark, USA) & 22.89 \\
& Compliments (Patents, USA) & 23.31 \\
\hline
\end{tabular}

We compared the cost of $20 \mathrm{~cm} \times 5 \mathrm{~cm}$ daily wound dressings, for one month, with five different materials (Figure 1). It was found that the panty liners cost $\$ 2.43$, sanitary napkins cost $\$ 5.54$, diapers cost $\$ 9.40$ and sterile abdominal pads cost $\$ 16.50$. In addition, the cost of daily finger dressings for one month using Coban tape $(\$ 0.66)$ versus sterile $2 \mathrm{~cm} \times 2 \mathrm{~cm}$ gauze was compared.

None of 20 sanitary napkins grew bacteria, one of 20 panty liners grew bacteria (coagulase-negative Staphylococcus), two of 20 sterile dressings grew bacteria (one coagulase-negative Staphylococcus and one nonhemolytic Streptococcus), 15 of 20 diapers grew bacteria (all bacillus) and two of five Coban rolls grew bacteria (one bacillus and one coagulase-negative Staphylococcus) (Table 3).

\section{DISCUSSION}

It is commonly believed that open wounds require sterile wound dressings to hinder the introduction of bacteria. We have not been able to find previous studies that have compared the sterility and cost of clean versus sterile dressing materials. The present study showed that panty liners, sanitary napkins and Coban tape were cheaper than, and had a sterility which was comparable with, the sterile gauze that we examined. None of 20 sanitary napkins grew bacteria, one of 20 panty liners grew bacteria (coagulase-negative Staphylococcus), two of 20 sterile dressings grew bacteria (one coagulase-negative Staphylococcus and one nonhemolytic Streptococcus), 15 of 20 diapers grew bacteria (all bacillus) and two of five Coban rolls grew bacteria (one bacillus and one coagulase-negative Staphyloccus).

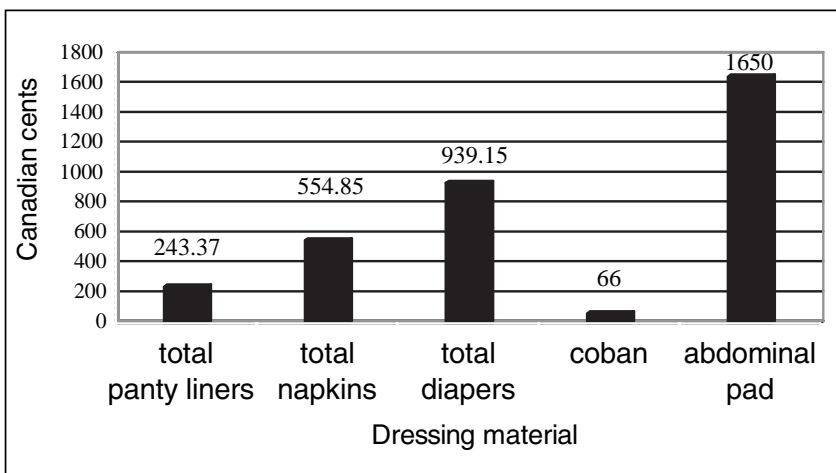

Figure 1) The cost (Canadian cents) of wound dressings for a month; a single unit/day, for 30 days

TABLE 3

Gram staining and culture results of each material

\begin{tabular}{|c|c|c|c|}
\hline Sample & & Growth & $\begin{array}{l}\text { Identified } \\
\text { organisms }\end{array}$ \\
\hline \multirow[t]{3}{*}{ Sterile gauze } & $2 \mathrm{~cm} \times 2 \mathrm{~cm}$ & $0 / 5$ & - \\
\hline & $4 \mathrm{~cm} \times 4 \mathrm{~cm}$ & $0 / 5$ & - \\
\hline & $4 \mathrm{~cm} \times 8 \mathrm{~cm}$ & $0 / 5$ & - \\
\hline \multicolumn{2}{|l|}{$\begin{array}{l}\text { Abdominal } \\
\text { pads }\end{array}$} & $2 / 5$ & $\begin{array}{l}\text { Coag-neg staph, } \\
\text { nonhemolytic strep }\end{array}$ \\
\hline \multirow[t]{4}{*}{$\begin{array}{l}\text { Sanitary } \\
\text { napkins }\end{array}$} & $\begin{array}{c}\text { Always (Procter \& } \\
\text { Gamble, USA) }\end{array}$ & $0 / 5$ & - \\
\hline & $\begin{array}{l}\text { Stay free (McNeill PPC, } \\
\text { USA) }\end{array}$ & $0 / 5$ & - \\
\hline & Compliments & $0 / 5$ & - \\
\hline & $\begin{array}{l}\text { Kotex (Kimberly-Clark, } \\
\text { USA) }\end{array}$ & $0 / 5$ & - \\
\hline \multirow[t]{4}{*}{ Panty liners } & Always & $0 / 5$ & - \\
\hline & $\begin{array}{l}\text { Care free (McNeill PPC, } \\
\text { USA) }\end{array}$ & $1 / 5$ & $\begin{array}{c}\text { Coag-neg staph } \\
-\end{array}$ \\
\hline & Compliments & $0 / 5$ & - \\
\hline & Kotex & $0 / 5$ & - \\
\hline \multirow[t]{5}{*}{ Diapers } & Pampers (Procter \& & $0 / 5$ & - \\
\hline & Gamble, USA) & & - \\
\hline & $\begin{array}{l}\text { Huggies (Kimberly-Clark, } \\
\text { USA) }\end{array}$ & $5 / 5$ & $\begin{array}{l}\text { Bacillus sp in } \\
5 / 5 \text { specimens }\end{array}$ \\
\hline & Compliments (Patents, US & SA) $5 / 5$ & $\begin{array}{l}\text { Bacillus sp in } \\
5 / 5 \text { specimens }\end{array}$ \\
\hline & Comfort (Patents, USA) & $5 / 5$ & $\begin{array}{l}\text { Bacillus } \mathrm{sp} \text { in } \\
5 / 5 \text { specimens }\end{array}$ \\
\hline \multicolumn{2}{|c|}{ Coban (3M, USA) } & $2 / 5$ & $\begin{array}{l}1 \text { Bacillus sp, } \\
1 \text { coag-neg staph }\end{array}$ \\
\hline
\end{tabular}

Coag-neg staph Coagulase-negative Staphylococcus; Sp Species; Strep Streptococcus

Many patients cannot afford sterile dressings. Patients are often discharged while the wounds are still healing and require that the wound be cared for by family members or outside hospital settings. In St John, clean dressings have been used instead of sterile dressings for years, with no apparent ill effects. Whether to use clean or sterile technique, in the management of acute and chronic wounds, is a question that researchers and clinicians have been asking and attempting to answer with certainty since the 1800 s. Because patient 
situations are unique, particularly in the home, the structured guidelines one finds for wound cleansing and dressing are not universally applicable (2).

A prospective, multicentre trial (3) enrolled 816 individuals, who were randomly assigned to have their wounds repaired using sterile or clean nonsterile gloves. There was no statistically significant difference in the incidence of infection between the two groups. The infection rate was $6.1 \%$ in the sterile gloves group and $4.4 \%$ in the clean gloves group. That study concluded there is no clinically important difference in infection rates between using clean nonsterile gloves and sterile gloves during the repair of uncomplicated traumatic lacerations (3).

We have found one pilot study of sterile versus clean technique in the postoperative wound care of patients with open surgical wounds, which showed no difference in the rate of wound healing with clean versus sterile technique (4). Staff from two acute care surgical units provided data for three months before and three months after standardization of wound care to a clean wound care technique. All adult patients requiring dressing changes three times per day, with normal saline-moistened gauze, of their open surgical wound(s) participated in that study. Before changing the wound care procedures, nine of 1070 (0.84\%) admissions to the two surgical units had a surgical site infection. During the three months following implementation of clean wound care protocols, eight surgical site infections were documented in 963 admissions $(0.83 \%)$. Dressing supply costs were $\$ 380$ less.
In the present study, using nonsterile wound care procedures for wounds healing by secondary intention did not negatively impact infection rates and saved supply costs (5).

\section{CONCLUSION}

Panty liners, sanitary napkins, diapers and Coban tape are much cheaper than sterile dressings. Based on the present study and our clinical experience, we feel that the traditional requirement for sterile dressings for open contaminated wounds deserves more study and possible reconsideration.

ACKNOWLEDGEMENTS: The authors thank Dr Kevin Forward and the microbiology department at Dalhousie University, Halifax, Nova Scotia for generously supporting this work. The authors have no commercial interest in the outcome of the present study.

\section{REFERENCES}

1. Karch AM, Karch FE. 'Clean' vs 'sterile'. Am J Nurs 2001;101:25.

2. Barber LA. Clean technique or sterile technique? Let's take a moment to think. J Wound Ostomy Continence Nurs 2002;29:29-32.

3. Perelman VS, Francis GJ, Rutledge T, Foote J, Martino F, Dranitsaris G. Sterile versus nonsterile gloves for repair of uncomplicated lacerations in the emergency department: A randomized controlled trial. Ann Emerg Med 2004:43:362-70.

4. Stotts NA, Barbour S, Griggs K, et al. Sterile versus clean technique in postoperative wound care of patients with open surgical wounds: A pilot study. J Wound Ostomy Continence Nurs 1997;24:10-8.

5. Lawson C, Juliano L, Ratliff CR. Does sterile or nonsterile technique make a difference in wounds healing by secondary intention? Ostomy Wound Manage 2003;49:56-8,60. 